\section{Media ethics \\ in wartime: \\ The code for \\ the coverage of the Colombian armed conflict}

La ética de los medios en tiempos de guerra: el código de la cobertura del conflicto armado colombiano

\author{
Ética dos meios de \\ comunicação em tempo \\ de guerra: 0 código para \\ a cobertura do conflito \\ armado colombiano
}

Yeny Serrano ${ }^{1}$

yeny.serrano@unistra.fr

University of Strasbourg

Strasbourg - Francia

Artículo recibido: 8/04/2014

Artículo aprobado: 11/05/2014

Para citar este artículo: Serrano, Y. (2014).

Media ethics in wartime: The code for the coverage of the Colombian armed conflict.

Ciudad Paz-Ando, 7(1), 164-177

DOI: http://dx.doi.org/10.14483/udistrital.jour. cpaz.2014.1.a09

\begin{abstract}
By analysing the "code for the coverage of the Colombian armed conflict", this paper argues that journalism ethics need to be understood not only as a matter concerning journalists. Ethics also depend on the context in which journalists do their job. In this respect, ethics codes in wartime function more as political acts of communication rather than just training documents. Therefore, the central thesis of this paper is that scholars and journalists should adopt a holistic approach to studying news reports and journalism ethics in order to take into account the role of sources and audiences in the reporting of news.
\end{abstract}

Keywords: ethics, armed conflict, strategy, journalists, Colombia, news. 


\section{Resumen}

Mediante el análisis del "código de la cobertura del conflicto armado colombiano", este trabajo sostiene que la ética del periodismo debe ser entendida no sólo como un asunto relativo a los periodistas. La ética también depende del contexto en el que los periodistas realizan su trabajo. En este sentido, los códigos de ética en tiempo de guerra funcionan más como actos políticos de la comunicación. Por lo tanto, la tesis central de este trabajo es que los académicos y los periodistas deberían adoptar un enfoque holístico para el estudio de los informes de prensa y la ética periodística a fin de tener en cuenta el papel de las fuentes y el público en la presentación de las noticias.

Palabras clave: ética, conflictos armados, estrategia, periodistas, Colombia, noticias.

\section{Introduction}

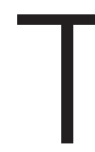
he coverage of wars and internal conflicts by mass media is often criticized, as in the particular case of the Colombian armed conflict. Journalists are blamed for disrespecting victims and reporting news in a way which favours one side of the conflict (Arias, Chacón, Cristancho, \& Quebedo, 2003; Bonilla, 2002; García Raya \& Romero, 2001). Journalists often state, in their defence, that they do their best and blame the pressure put on them by the sources as well as media ratings requirements. They also accuse the armed groups of manipulation (Giraldo, Roldán, \& Flórez, 2003; MPP, 2006). In this context, some journalists have explored how to respond to these pressures, and one of

\section{Resumo}

Ao analisar o "código para a cobertura do conflito armado colombiano" este artigo argumenta que a ética do jornalismo precisa ser entendida não apenas como uma questão relativa aos jornalistas. Ética também depende do contexto no qual os jornalistas realizam seu trabalho. Neste sentido, os códigos de ética em tempo de guerra funcionam mais como atos políticos de comunicação do que apenas redação de documentos. Portanto, a tese central deste trabalho é que os académicos e jornalistas deveriam adotar uma abordagem holística para os estudos das reportagens e da ética jornalística, a fim de levar em conta o papel das fontes e o público na apresentação das notícias.

Palavras-chave: ética, conflito armado, estratégia, jornalismo, Colômbia, notícias. the means identified for improving their working conditions has consisted of writing ethics codes. Nevertheless, ethics in journalism are usually associated with ideas of how journalists should do their job in a morally correct way (Sanders, 2010). However, the improvement of news production depends not only on the actions of journalists. As this paper attempts to argue, there are variables outside of the media which also affect journalists' work and limit the scope of ethics codes.

Before explaining these variables, it would be relevant to point out that discussions about journalism ethics are not new; Stephen Ward identifies five stages in the development of journalism ethics: 
1. The invention of an ethical discourse during the seventeenth century.

2. The creation of a "public ethics" code based on the idea that the press plays the role of a Fourth State.

3. The liberal theory of the press during the nineteenth century.

4. The development and criticism of this liberal doctrine, resulting in a professional ethics of objective journalism.

5. A "mixed-media" ethics which lacks consensus on which principles apply across different types of media. (Ward, 2009, p.295)

Evidently, since the profession began, journalists have been concerned about the appropriate way to report news. Thus, ethics codes are documents which provide clarity in the form of principles and standards to which journalists should adhere in specific situations in order to do their job 'well' (Ward, 2009, p.296). Nonetheless, a significant number of cases show that journalists constantly transgress their own professional codes, especially in wartime. As said before, such is the case of the coverage of the Colombian armed conflict. While Colombian journalists commit to reporting truthful, accurate and balanced information in their professional and training documents (Castro, Villamizar, Restrepo, \& Guerrero, 2005; CPB, 1990; El Colombiano, 2003; El Tiempo, 2003; Márquez González, 2003; MPP, 2006), the analysis of news reports has shown that news about the armed conflict are unbalanced and biased in a way which favours one side of the conflict (Flores \& Crawford, 2001;

López, 2003; Serrano, 2012).
More specifically, this paper argues that The code for the coverage of the Colombian armed conflict (Márquez González, 2003) ${ }^{2}$ is not a professional document addressed to journalists in order to tell them how to cover the conflict. The code is a political act of communication addressed to the audiences, armed groups (journalists' sources), media owners and managers. In fact, the analysis of the context in which the code was written, along with its content, suggests that the journalists' principles of accuracy, impartiality and neutrality are not compatible with the strategic military aims of the armed groups who are also journalists' sources. Accordingly, this paper seeks to explain why the principles set in the code appear to be contradictory to the context in which journalists have to work. The paper also argues that the strategy of the code is to claim editorial independence from media organizations and armed sources as well as to justify professional and ethical mistakes to various audiences.

This argument is consistent with literature advocating for a more comprehensive approach to ethics in journalism (Ward, 2005) and the definition of journalism ethics codes as documents framed by specific ideological, political and social influences (Wilkins \& Brennen, 2004). For this purpose, the next section describes briefly the context and the content of "the code for the coverage of the Colombian armed conflict". The third section then examines how the context of war affects the work of journalists and why the code cannot be a training document. The paper concludes by supporting the idea that a holistic approach to journalism ethics and ethics codes is vital, and that these ought to be treated as something more than mere professional tra-

2 Available at http://bit.ly/1rF1dKm 


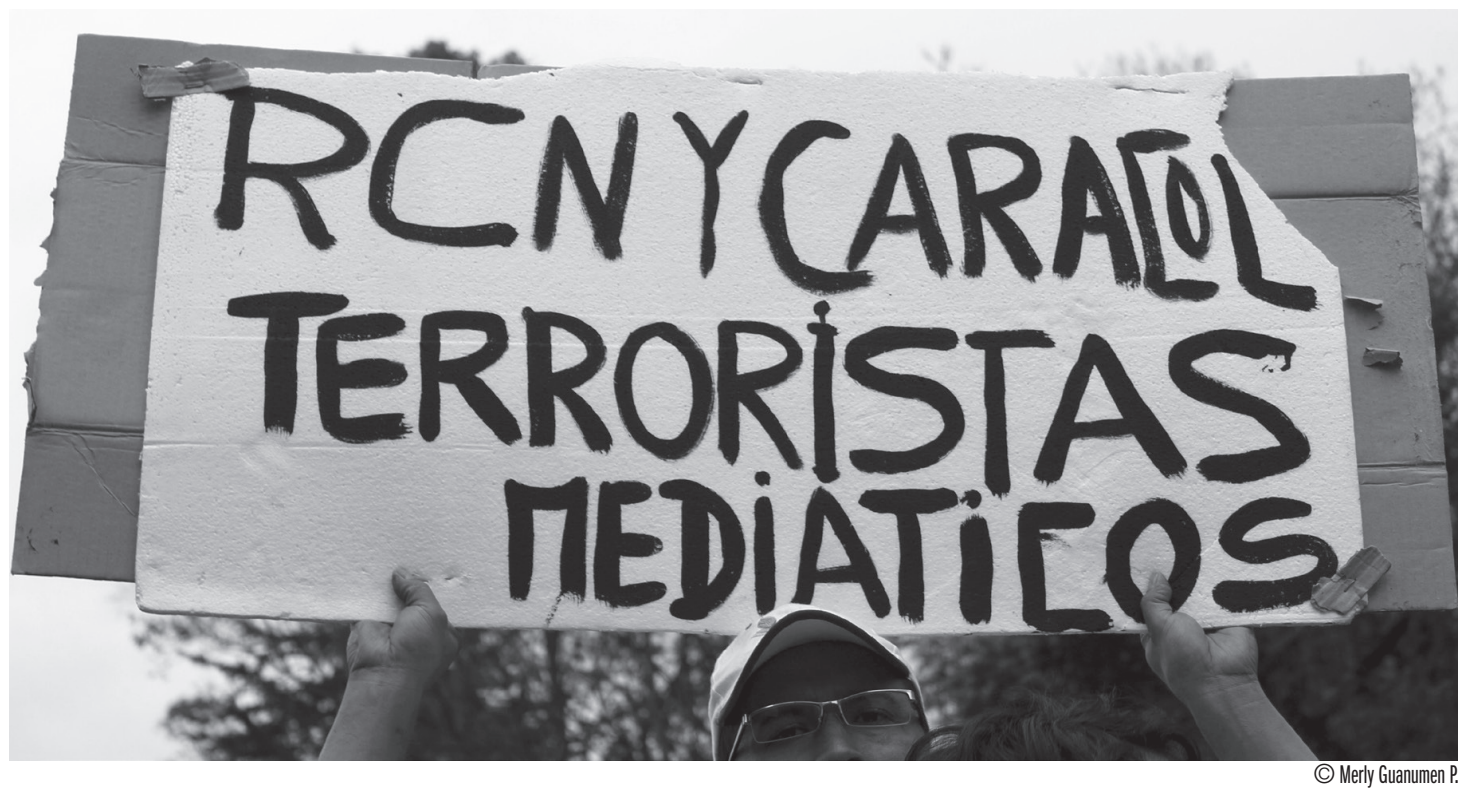

ining documents. This argument is of particular importance since new peace dialogues started between the Colombian government and the largest and oldest guerrilla group in the country (the FARC ${ }^{3}$ ). Indeed, if journalists are concerned about how to cover the armed conflict, then it becomes all the more important for them to think about how their professional standards ought to be adapted for covering the peace process and promoting peace, if media organizations decide to do so.

\section{Ethics and journalism in Colombia: The code for the coverage of the Colombian armed conflict}

Before Colombian journalists wrote an ethics code specifically applicable to the coverage of the conflict, the professional association Círculo de periodistas de Bogotá 4 had written a more general code: "Code of ethics and responsibility of journalists" (CPB, 1990). The purpose of this code is to "point out to jour-

Revolutionary Military Forces of Colombia.

Bogota Journalists Circle. nalists a set of basic principles of behaviour based on rational principles of ethical and professional behaviour" (CPB, 1990). The code proclaims the ideal of the veracity of news and independence from sources. It states that the main obligation for journalists is to inform in an accurate and comprehensible way. This code is taught in journalism schools and still functions as a reference for Colombian journalists concerning the main professional principles and values.

Nevertheless, in 2003 a code for the coverage of the Colombian armed conflict was written by the head of the Centro de Solidaridad de la Federación Internacional de Periodistas ${ }^{5}$ and founding member of the professional association Medios para la Paz (Márquez González, 2003). At that time, the situation for journalists in Arauca (one of the regions where the armed conflict has been the most intense) had become very difficult. Most of the journalists covering the conflict in Arauca had left because of threats from the armed

Centre of Solidarity of the International Federation of Journalists. 6 Media for Peace. 
groups. For this reason, a code applying exclusively to the coverage of the armed conflict was published. The document is organised in three parts ${ }^{7}$ : an outline of the issues, a list of standards to which journalists should adhere, and a conclusion. The first part states three considerations on which the code is based:

1. The right to information and the political commitment of journalists to society and to the truth from an ethical point of view.

2. Covering the armed conflict supposes that any message provided by an armed group, legal (the military) or illegal (paramilitary and guerrilla groups), may be propaganda which seeks to favour the particular interests of the group.

3. Journalists are citizens whose mission is to inform other citizens by working towards the common good. For journalists information is a social good. They condemn violence as a method of conflict resolution. They recognise that their duty is to cover war, without obscuring or exaggerating its causes, consequences and context.

These first three considerations illustrate the ideal of accurate, truthful and balanced reporting. This approach to journalists' work is what Stephen Ward calls the objectivity and social responsibility model (Ward, 2009, pp.298299), which means that journalists adhere to "objectivity" as a dominant ethical idea. This ideal of objective news reporting includes the claim of independence from government and business influences, and a strict distinction between news and opinion. This model corresponds to one of Ward's five ethics development stages: the development and criticism

7 The author of this paper translates and summarizes the most important parts of the text. The original text in Spanish can be download at: http://bit.ly/1rF1dKm of the liberal doctrine during the 20th century resulting in a professional ethics guideline of objective journalism (Ward, 2009, p.295). However, scholars have pointed out some issues which make objectivity more of an "ideal" than an actual professional practice (Chalaby, 1998; Serrano, 2007; Tuchman, 1972), and have highlighted the need to better understand what "objectivity" means for journalists. For instance, in the 1970s, Guy Tuchman demonstrated that "'objectivity" may be seen as a strategic ritual protecting newspapermen from the risks of their trade" (1972, p.660). More recently, Jean Chalaby (1998) stated that the norm of objectivity is quite a recent invention consisting of discursive norms (such as factuality, accuracy, neutrality, impartiality, balance and fairness), which emerged with the policy of non-alignment towards political parties that newspapers began to follow in the course of the 19th century (during the rise of mass media and commercial press). In other words, while for some journalists, scholars and even audiences, objectivity is associated with impartial reporting, in practice, objectivity is a term that journalists use to define news which claims to be free from the influence of political parties or other sources of pressure (Serrano, 2007).

The three considerations included in the code for the coverage of the Colombian armed conflict also demonstrate journalists' awareness of the manipulation exerted by the armed groups. Nevertheless, the code is a document written only by journalists. Audiences and actors involved in the conflict did not participate in its writing, thus the standards set in the code correspond exclusively to journalistic logic. The problem with this logic is that the ethical idea of objectivity does not correspond to the "reality" of the social actors involved in the conflict. For instance, journalists 


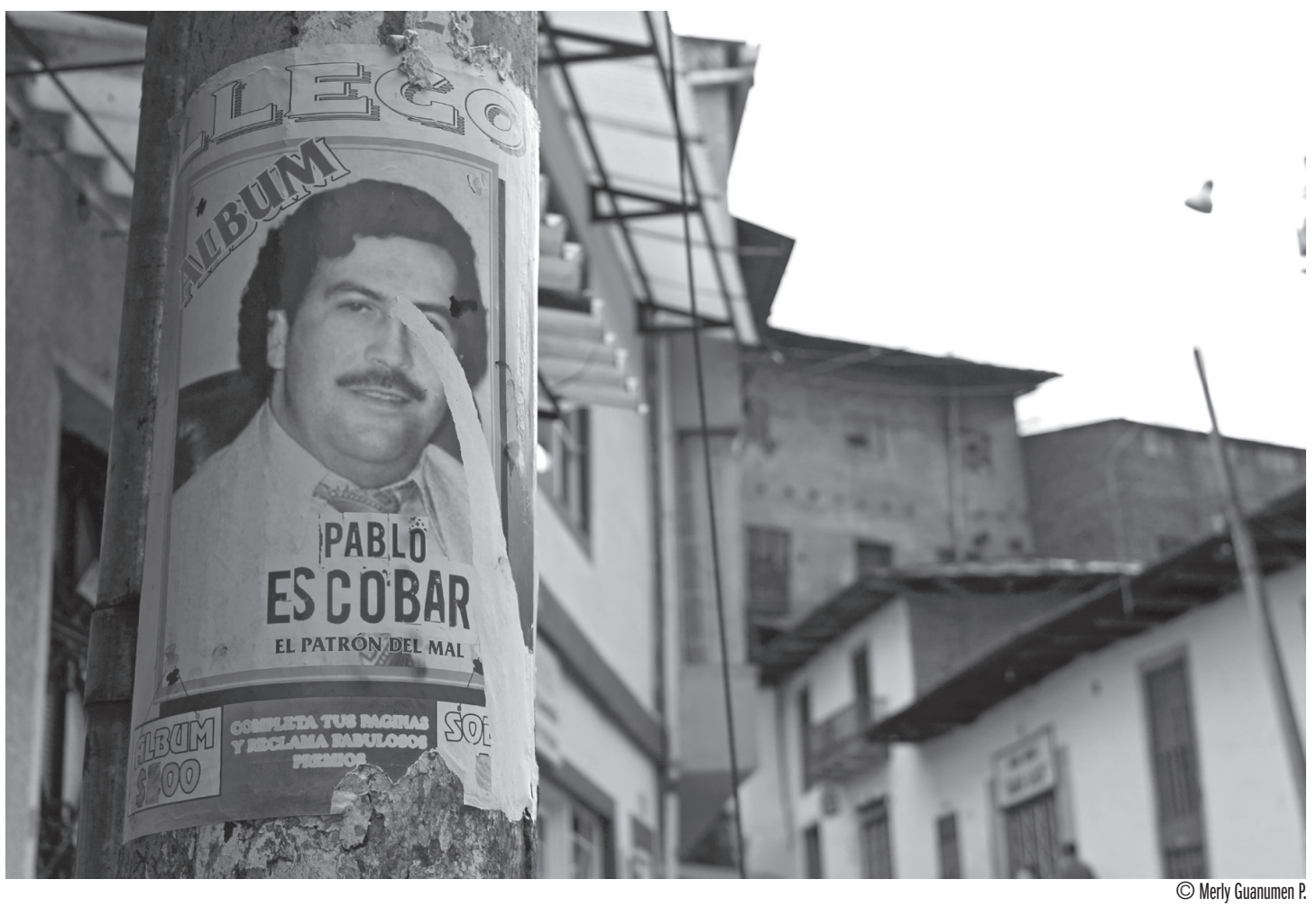

condemn violence but at the same time news value for media organizations is essentially based on conflict and drama. Good "news" is not newsworthy for media organizations. As Gadi Wolfsfeld $(2001,2004)$ and Dov Shinar state $(2003,2004)$, conflict and violence are more compatible with media professional standards. War provides media with material for improving ratings; consequently, the manipulation exerted by armed groups could, to a certain extent, be very useful in terms of increasing media ratings, and this is at odds with the professional values that journalists associate with truthful reporting.

The second part of the code lists nine principles to which journalists commit. Five of them concern the relationship with sources (state, legal and illegal social groups):

1. We will keep a strictly professional relationship with our sources (...). We reject discrimination, coercion, intimidation or any privilege which could compromise our independence.

2. We will not reveal the identity or location of sources if asked (...).

3. We will make a particular effort to verify information with different sources. We will compare and verify any statement provided during interviews, press conferences or through press releases. (...) If we have only one source, we will explain that the report is based on only one version.

4. We will enrich media coverage of the war by allowing any citizen to express their opinion and peace proposals. We believe that peace is the most important outcome $(. .)^{8}$.

8 The journalists' commitment to peace deserves to be highlighted. In the last section, this paper discusses the contribution of ethics to peace building. 
5. Under no circumstances will journalists assume the functions of any legal state institution or an illegal centre of intelligence or any humanitarian organization (...).

A second set of principles relates to news format:

1. We will use an adequate lexicon which avoids qualifying expressions and adjectives used by the groups in conflict. We will respect the right to the presumption of innocence and refer to a person suspected of having committed a crime as a "suspect" until the issuing of a final and appealable conviction. Under no circumstances should a journalist be an instrument of war.

2. We are not responsible for the final news outcome because professional practice determines that journalists are only responsible for the coverage and writing of news. The titling, editing and broadcasting or publication of a news report are the responsibility of media owners and managers.

The last principles relate to victims of the conflict, and the journalists' role with regard to the media and the state:

1. We will respect the privacy of citizens involved in or affected by the armed conflict, provided that this silence will not compromise the public interest. In all instances we will respect the grief of the victims.

2. We will fulfil our duties of loyalty and availability as media within the framework of journalism ethics, which requires truthful information and sets aside any economic interest, within the limits of security [for journalists]. In order to ensure our independence, we need sufficient and adequate salaries (...) and also a means of transport which is not owned by parties of
The code concludes by stating that "when an armed group thinks that they have the right to use, manipulate or intimidate a journalist, they do so because they think that reason comes from weapons. For journalists, reason comes exclusively from truth" (Márquez González, 2003).

In other words, this code allows journalists to respond to the threats they have received by blaming the manipulative tactics of the armed groups and the use of weapons. At the same time, it states how they are to do their job in this context: by making a commitment not to rely on the war lexicon of armed groups, by contrasting sources, and by respecting legal institutions and civilians. However, these particular commitments result from a particular context which is explained in the next section.

\section{Ethics in wartime}

In order to understand what the code for the coverage of the Colombian armed conflict means in the current context, it is necessary to remember that news reports are not only a matter for journalists. Previous research has shown that the form and content of the news which is produced and broadcast are influenced by media, journalistic and war communications. These variables also play a role in journalism ethics, as this paper seeks to demonstrate.

Media and journalistic variables refer to journalists' obligation to follow the demands imposed by media organisations, including political bias, formatting constraints and ratings requirements - while taking care to maintain credibility and dealing with the pressure exerted by sources (Berkowitz, 2009; Carlson, 2009; Charaudeau, 2005; McQuail, 2010). Thus, when journalists state in their code that they will keep an independent re- 


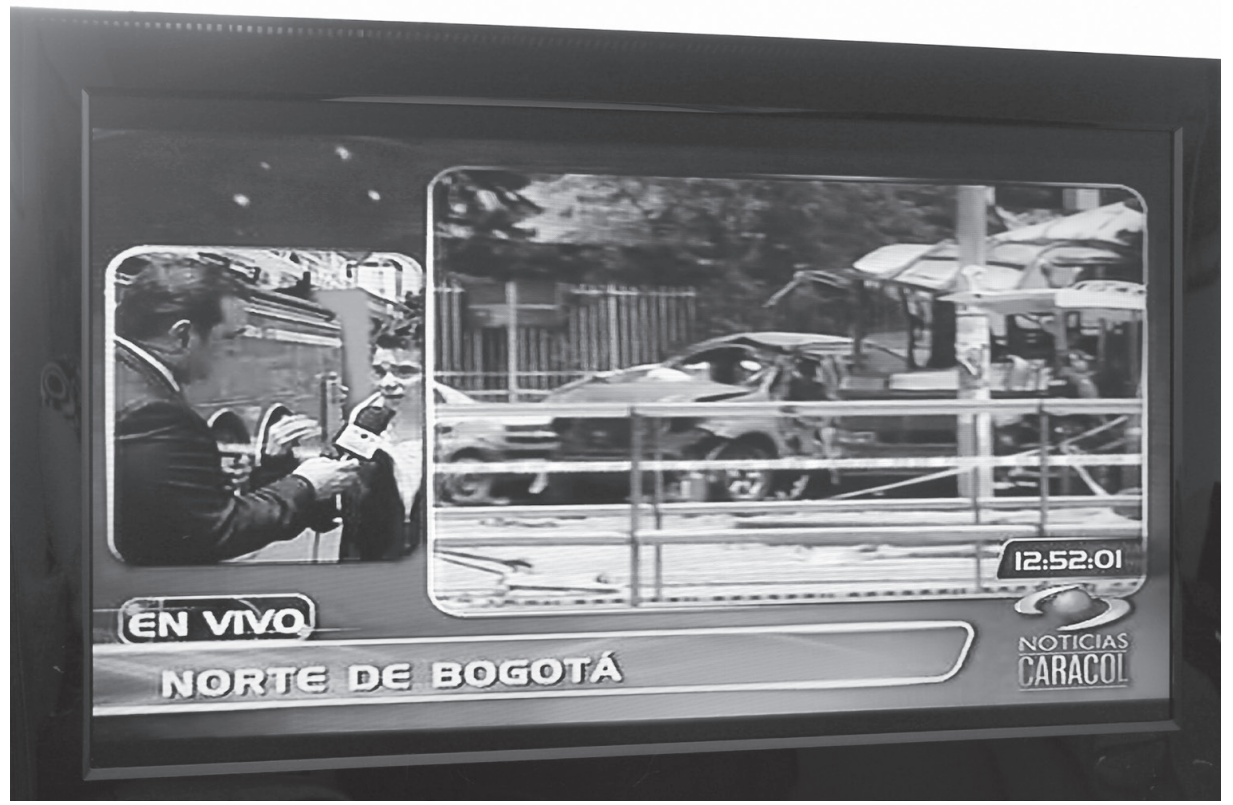

C Merly Guanumen P.

lationship with sources and verify information provided by them, they seem to be unaware of the context in which they produce news. For instance, in Colombia, news production and broadcasting is the function of private media owned by the richest families in the country who also have family connections in the government. The current president, Juan Manuel Santos (2010-2014), is a member of the family who owns the most important newspaper, El Tiempo, and his nephew, Alejandro Santos, is the Editor-in-Chief of Semana, the main news magazine in the country.

Moreover, some media owners have decided to support the State and put pressure on their employees (journalists) to favour official sources when covering the conflict. In other words, current working conditions are at odds with the ethical principles which journalists commit to. In their ethical code, journalists acknowledge that good salaries and resources for covering the conflict are indispensable. However, economic constraints lead media owners to reduce the human and technical resources allocated to covering conflict zo- nes. As a result, the quality of news leaves a lot to be desired, as Colombian scholars and journalists have pointed out (Bonilla \& Patiño, 2001; Bonilla, 2002; López, 2003, 2005; MPP, 2006; Rincón \& Ruíz, 2002a, 2002b). In order to respond to the pressure exerted by the armed groups, journalists have created some professional myths. For example, they prefer to quote the position of the Church because it is supposed to be neutral. Journalists also think it is better to voice the opinion of official sources because they must take responsibility for whatever is said (Rincón \& Ruíz, 2002a, 2002b). The main problem with this is that official sources - government, military and State representatives - are also parties in the conflict and are therefore not impartial. When they talk to journalists, they seek to influence the way news media frame the conflict and the groups involved in it?.

9 For a deeper analysis on the recent conditions in which Colombian journalists cover the armed conflict, we particularly recommend the work of Rousbeh Legatis (2010). The author especially focuses on structural media organizations problems which affect the quality of news. He describes the media national landscape and also highlights the efforts made by some journalists to cover the conflict in a better way despite the deficiencies in training and pro- 
This point is related to the third group of variables involved in news production, these being war communications variables, because armed groups and official sources involved in the conflict are only interested in winning the war. They are not interested at all in informing citizens in an "objective" way (Hoskins \& O'Loughlin, 2010; Maltby \& Keeble, 2007; Maltby, 2012a). When groups involved in conflict talk to journalists, their motivation is to influence journalists to talk about the war from their own point of view; that is, to justify their violence whilst discrediting the adversary. In the particular case of Colombia, the military requires the unconditional support of journalists. For instance, during the previous peace dialogues held between 1999 and 2002, some military representatives "invited" media managers to constantly change correspondents, in order to prevent journalists covering the dialogues from becoming "friends" with the guerrilla fighters (Bonilla, 2002; Rincón \& Ruíz, 2002a). In fact, the government does not accept that journalists should give the same treatment to legal armed forces and guerrillas. It is for this reason that the Colombian State has made arrangements to prevent journalists from using members of illegal groups as sources (CNTV, 1997; Giraldo et al., 2003; López, 2005). The only occasions where journalists are permitted to interview members of illegal armed groups are when these groups are engaged in peace dialogues with the government. In this sense, when journalists say in their code that armed groups use them to disseminate propaganda, they are recognising that news is not only their preserve, but that other social actors also play a role in the reporting of news. One might, therefore, ask why journalists then set standards as if news reporting exclusively depended on them. Given that they are not allowed by the state to interview all the actors involved in the conflict, they are not able to respect the plurality and balance of sources. In this sense, the context of war interferes with journalists' ethical principles. However, journalists mainly adopt an internal approach in their discussions and initiatives regarding ethics. Indeed, as Stephen Ward argues, the

efforts to reform news media practices are polarized between two inadequate approaches; an 'internal' approach which considers journalism ethics the exclusive domain of journalists (as is illustrated by the code for the coverage of the Colombian armed conflict), and an 'external' model which supports the idea that reform requires the imposition of external regulations and regulators on news media. (Ward, 2005, p.315)

The main problem with both approaches is that they neglect to consider the fact that journalists' news reports result not only from what journalists do, but also from the context in which news are produced and the influence of other social actors involved.

\section{Discussion}

\section{Ethics in wartime}

Looking to understand better the role of the ethics codes in news reports covering wars and armed conflicts, this paper examined the case of "the code for the coverage of the Colombian armed conflict". The aim was to argue that the constraints of mass media (both symbolic and economical), as well as the strategic aims of the armed groups, cannot be compatible with balanced, neutral and accurate reporting of wars. By examining the context in which the code for the coverage of the 


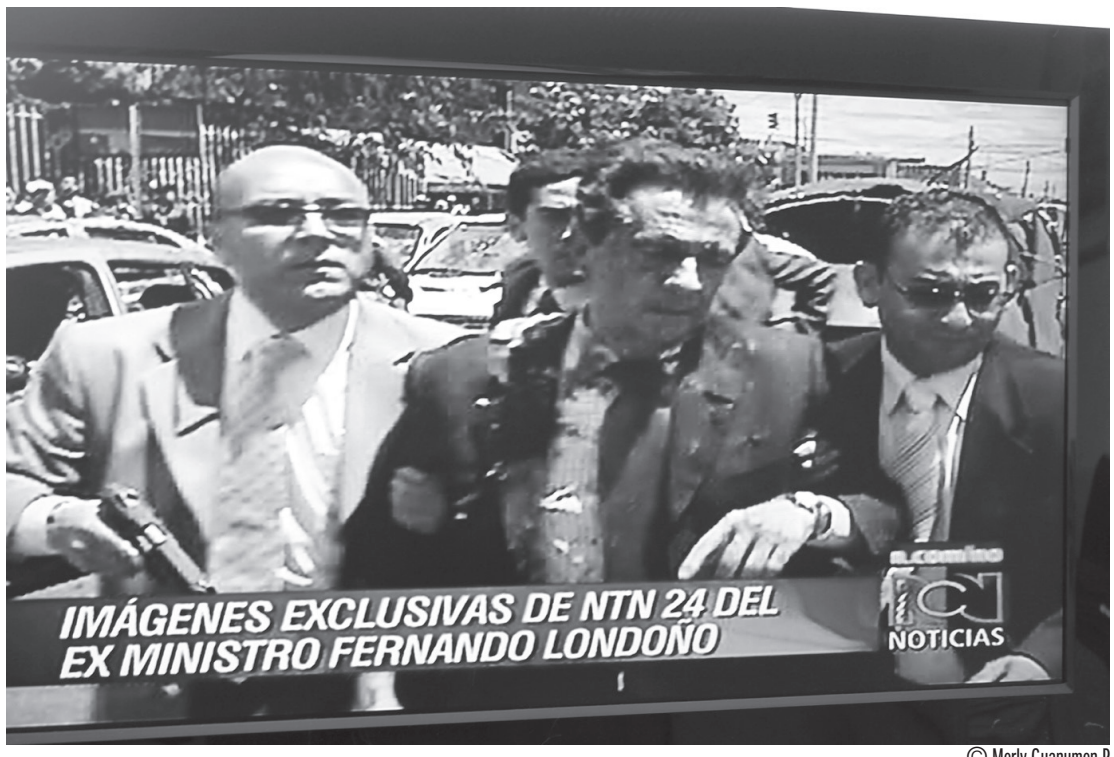

Colombian armed conflict was written and the kind of principles set therein, one might ask:

- Why should journalists include in their ethics code principles that they know in advance they will not be able to follow because of the constraints resulting from the context of war?

- Why do journalists establish a code in which they commit to reporting truthful and balanced information, when official sources are directly involved in the conflict and have the legitimacy to prevent journalists from verifying information with sources who do not represent their point of view?

This paper argues that the way in which scholars and journalists have studied news reports and journalism ethics in wartime needs to be discussed in a more comprehensive way. Firstly, news reports on war are not only affected by media organizations' constraints and journalists' work. In times of war, media is one of the "weapons" used by the parties in the conflict in order to communicate their legitimi- zing discourses (Hoskins \& O'Loughlin, 2010; Maltby, 2012b). Taking this into consideration, there is no reason for ignoring this fact when discussing journalism ethics in wartime, nor will merely denouncing it solve the problem. Secondly, concerning the code for the coverage of the armed conflict, Colombian journalists wrote it because of threats they had received from armed groups; therefore the original purpose of the code was not that it be used as a professional training document, nor as a guideline for journalists.

The code's purpose extends beyond that of a document telling journalists how to cover the armed conflict in a responsible way; the code is aimed at media owners and managers, armed groups and media audiences. In this sense, the code is a "political act of communication" (Ward, 2009) responding to a particular context (Wilkins \& Brennen, 2004). With the code, Colombian journalists are telling the armed groups that their motivations and aims are not the same, that they defend different principles and that they disapprove of the coercion exerted by the armed groups. 
Journalists are also telling their audience that their margins for manoeuvre are limited because of the pressure from the armed groups, which could explain their "mistakes". Thus, if they publish information which is inaccurate and biased, it is not their fault but that of the armed groups who manipulate them and of the media owners and managers who do not provide them with appropriate working conditions. Finally, Colombian journalists are also demanding editorial independence from media owners and managers. In this sense, this study supports Ward's proposal (2005) regarding the need to adopt a holistic ethical approach when considering the role of sources and audiences in the reporting of news. This holistic approach to journalism ethics would allow journalists to establish clearer guidelines on how to respond to the constraints of a war context.

\section{Ethics in peace building}

As it was noted previously, this is even more important in the current context of peace dialogues. It is evident that Colombian journalists have mainly focused their attention on how they should cover war and much less on how they should cover peace. Even if they state in the code for the coverage of the conflict that peace is the most important outcome, the way in which media organizations function is more coherent with war and conflict than with peace. Within the perspective of post-negotiation, conflict management and peace building in Colombia, it seems worth questioning the extent to which existing professional documents, such as ethics codes, are adapted to cover and promote peace. If the professional value of truthful, balanced and unbiased news reports is deemed unattainable in a war ints and pressure exerted by sources and armed groups -, could these values be relevant within a peace building context? In any event, journalism ethics should correspond to the context in which journalists do their job, by taking into account all social actors involved in news production.

Scholars who analysed how media could contribute to peace considered ethics to be of key importance. First, they found that a large amount of research has focused on media and conflict but only a few studies have concentrated on media in peace processes (Shinar, 2004; Wolfsfeld, 2001). These studies point out that the way in which news media have been covering wars and armed conflicts negatively affects the way in which they could cover peace-building. As Gadi Wolfsfed argues, when news media cover peace processes, they usually have a non-constructive role. They adopt what Dov Shinar calls an "endof-conflict-expectations" model, which makes news media focus on crises, the escalation of violence and recent events. Thus, typical peace coverage concentrates on press conferences with "talking heads", or on crises - which, incidentally, could just be a normal part of the negotiation processes - by amplifying them.

Gadi Wolfsfeld (2004) has identified variables which could make media take on a constructive role in peace processes, and Dov Shinar talks about the adoption of a "transformation model" (2003, 2004). Both scholars argue that to contribute to peace building, news media need to deconstruct their war discourses in order to help audiences understand the complexity of a peace process. An armed conflict does not end as soon as both parties involved have signed an agreement. Adrian Guelke (2003) states that the implementation of a peace agreement may be longer and more complicated than 


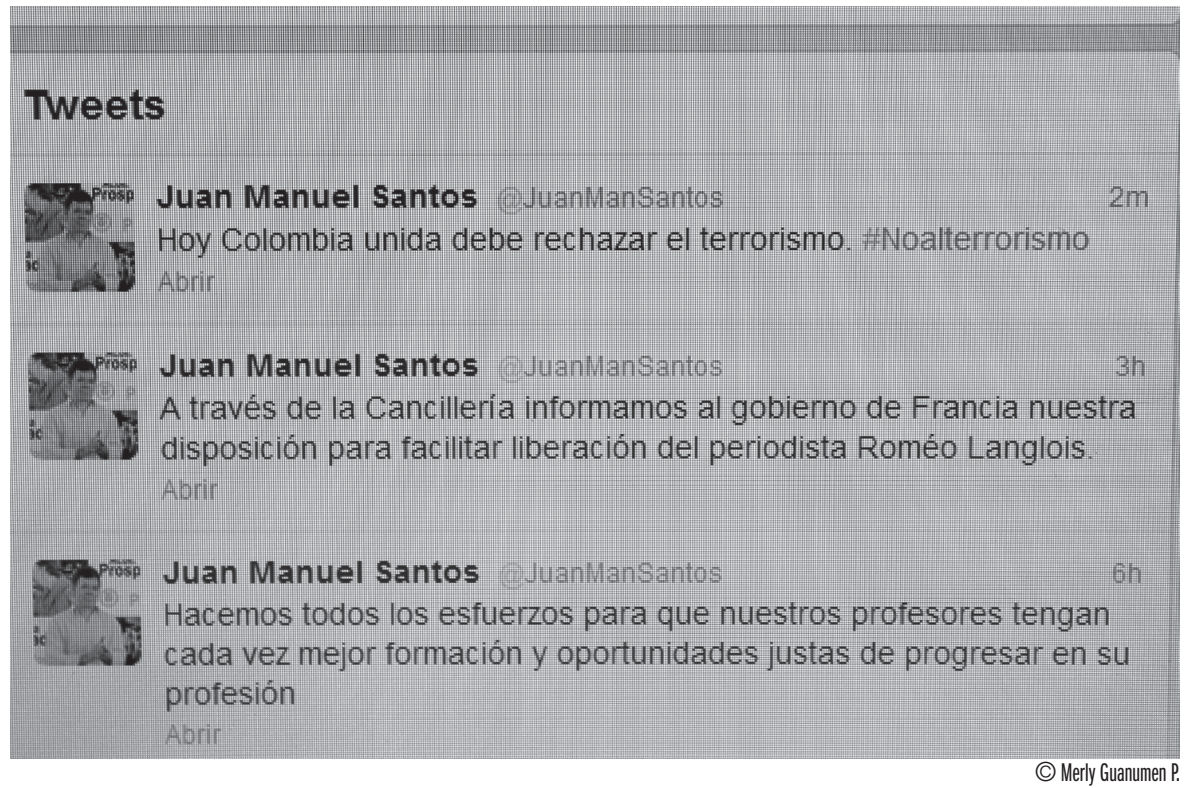

reaching the agreement itself. Instead of focusing on recent facts, short statements from spokesmen and crises, news reports could turn their attention to collective values and historical insight. More specifically, variables associated with the political environment and the media environment are likely to have a constructive influence on how news media cover peace. The political environment variables refer to beliefs, discourses and behaviours concerning political matters.

By analysing the Oslo peace process, the outbreak of the Second Intifada and the Good Friday Agreement in Northern Ireland, Gadi Wolfsfeld demonstrated that political control leads to media control. More specifically, he found that "the greater the level of elite consensus in support of a peace processes, the more likely the news media will play a positive role in that process" (Wolfsfeld, 2004, p.26). The political environment is also associated with crises in peace processes: "the greater the number and severity of crises associated with a peace processes, the more likely the news media are to play a negative role in the process" (Wolfsfeld, 2004, p.30). These statements are consistent with this paper's argument about the necessity of adopting a holistic approach to journalists' work and journalism ethics.

In addition to the political environment, there are media environment variables that help news media contribute to peace. G. Wolfsfeld showed that

the more sensationalist the media environment, the more likely the news media are to play a destructive role in a peace process. The notion of sensationalism refers to the extent to which journalists feel obliged to use a melodramatic style of presentation in the construction of news stories. (2004, p.40)

This tendency of some media organizations in western democracies to favour sensationalism for news production explains why war and conflict are more newsworthy than peace. Moreover, "the greater the extent of shared media, the more likely it is that the news media will play a constructive role in 
a peace process" (Wolfsfeld, 2004, p.42). In fact, when the parties engaged in a peace process are not informed by the same news media, news reports tend to reinforce stereotypes by pointing out the disagreement between "them" and "us". In the current Colombian context, one can assume that both parties share the same news media, in the sense that both parties are Colombian. Nevertheless, as previous research has shown, news media do not portray antagonists equally. The government's adversary is more often portrayed in a negative way (Serrano, 2011, 2012).

Proposals on how news media could contribute to peace are often criticized because a peace-oriented media discourse could imply a loss of objectivity on the part of journalists. This kind of criticism presupposes that news media cover wars and conflicts in an "objective" way, which is not the case, as a large amount of previously quoted research has demonstrated. This kind of criticism does not take into account that journalists' work is not only a matter for journalists, as this paper argues. Indeed, one cannot deny that peace-oriented discourse, as well as war-oriented discourse, is biased. Some scholars believe that, instead of considering this bias as a "problem", journalists should justify and base this bias on ethics. The work of journalists depends on how other social actors influence news production processes, and it is precisely because of this that the adoption of a holistic approach of journalism ethics could better respond to the needs of a peace process. Journalists should produce professional documents in which they set the journalistic, media and war communication variables influencing the way they construct stories about war and peace. They should also include values in which they justify a peace-oriented bias, in order to let sources and audiences know the point of view they will present in news reports. This kind of commitment would require the engagement of journalists as well as media managers due to the structural and administrative decisions that would be needed.

\section{References}

- Arias, E., Chacón, L., Cristancho, F., \& Quebedo, N. (2003). Tratamiento de los actos violentos en los noticieros de la televisión colombiana, Trabajo del grupo de investigación de la Escuela de Comunicación Social y Periodismo. Bogotá, Colombia: Universidad Sergio Arboleda.

- Berkowitz, D. (2009). Reporters and Their Sources. In K. Wahl-Jorgensen \& T. Hanitzsch (Eds.), The Handbook of Journalism Studies (pp.102115). New York: Taylor \& Francis.

- Bonilla, J. I. (2002). Periodismo, Guerra y Paz. Campo intelectual periodístico y agendas de la información en Colombia. Signo Y Pensamiento, 21 (40), 53-70.

- Bonilla, J. I., \& Patiño, G. (Eds.). (2001). Comunicación y política: viejos conflictos, nuevos desafíos. Bogotá, Colombia: Centro Editorial Javeriano.

- Carlson, M. (2009). Dueling, Dancing, or Dominating? Journalists and Their Sources. Sociology Compass, 3(4), $526-542$.

- Castro, G., Villamizar, D., Restrepo, A., \& Guerrero, A. (2005). Diccionario para desarmar la palabra (2. ed.). Bogotá, Colombia: Corporación Medios para la Paz, Planeta.

- Chalaby, J. K. (1998). The Invention of Journalism. Basingstoke: Macmillan.

- Charaudeau, P. (2005). Les médias et l'information: l'impossible transparence du discours. Bruxelles: De Boeck.

- CNTV. (1997). Servicio Público y Cobertura, Sistema de Televisión en Colombia. Bogotá, Colombia: Comisión Nacional de Televisión.

- CPB. (1990). Código de ética y responsabilidad del periodista. Círculo de Periodistas de Bogotá. Retrieved from http://www.mediosparalapaz.org/ index.php?idcategoria $=769$

- El Colombiano. (2003). Manual de estilo y redacción. Colombia: Impolibros S.A.

- El Tiempo. (2003). Conflicto armado y terrorismo. Manual de cubrimiento, El conflicto armado en las páginas de El Tiempo. Bogotá: Casa Editorial El Tiempo.

- Flores, P., \& Crawford, L. (2001). El papel de los relatos noticiosos en la construcción de un proyecto comunicativo para la paz en Colombia Diálogos de La Comunicación, 61, 46-55.

- García Raya, M. E., \& Romero Rodríguez, E. (2001). Las trampas de la aparición. Información y conflicto en Colombia. In J. I. Bonilla \& G. Patiño (Eds.), Comunicación y Política. Viejos conflictos, nuevos desafíos (pp.366-391). Bogotá, Colombia: Centro Editorial Javeriano.

- Giraldo, D., Roldán, I., \& Flórez, M. A. (2003). Periodistas, guerra y terrorismo (1. ed.). Bogotá, Colombia: Planeta, Escuela de Comunicación Social y Periodismo Universidad Sergio Arboleda. 
- Guelke, A. (2003). Negotiations and Peace Processes. In J. P. Darby \& R. M. Ginty (Eds.), Contemporary Peacemaking: Conflict, Violence and Peace Processes (pp.53-64). New York: Palgrave Macmillan.

- Hoskins, A., \& O'Loughlin, B. (2010). War and Media (1st ed.). Cambridge: Polity Press.

- Legatis, R. (2010). Conflict fields of journalistic praxis in Colombia. Conflict \& Communication Online, 9(2). Retrieved from http://bit.ly/1qZhp7V

- López, F. (2003). Ética periodística, verdad noticiosa sobre el conflicto armado y reconciliación nacional en Colombia. Presented at the Conference: Caminos para salir de la violencia, Frankfurt.

- López, F. (2005). Aprendizajes y encrucijadas del periodismo. Entre la paz de Pastrana y la seguridad democrática de Uribe. Palabra Clave, 13, $7-45$.

- Maltby, S. (2012a). Military Media Management: Negotiating the "front" line in mediatized war (1st ed.). London ; New York: Routledge.

- Maltby, S. (2012b). The mediatization of the military. Media, War \& Conflict, 5(3), 255-268.

- Maltby, S., \& Keeble, R. (Eds.). (2007). Communicating War: Memory, Media and Military. Suffolk: Arima publishing.

- Márquez González, E. (2003). Código para el cubrimiento del conflicto armado colombiano. Retrieved from http://bit.ly/1rF1dKm

- McQuail, D. (2010). McQuail's Mass Communication Theory. London: SAGE Publications Ltd.

- MPP. (2006). Prensa, conflicto armado y región. Aprendizajes del diplomado Periodismo responsable en el conflicto armado. Bogotá: Corporación Medios para la paz.

- Rincón, O., \& Ruíz, M. (2002a). Bajo todos los fuegos : los periodistas en el conflicto colombiano (1. ed.). Bogotá, Colombia: Proyecto Antonio Nariño.

- Rincón, O., \& Ruíz, M. (2002b). Más allá de la libertad. Informar en medio del conflicto. Signo Y Pensamiento, 21(40), 72-86.

- Sanders, W. (2010). Documentary Filmmaking and Ethics: Concepts, Responsibilities, and the Need for Empirical Research. Mass Communication and Society, 13(5), 528-553.

- Serrano, Y. (2007). L'"objectivité" journalistique : droit des citoyens, devoir des journalistes ? C@hiers de Psychologie Politique, (10). Retrieved from http://bit.ly/1qxmlF3

- Serrano, Y. (2011). La mort des victimes civiles et des combattants dans les discours d'information des journaux télévisés. Le conflit armé en Colombie. Questions de Communication, (20), 79-104.

- Serrano, Y. (2012). Nommer le conflit arme et ses acteurs en colombie communication ou information mediatique. Paris: L'Harmattan.

- Shinar, D. (2003). The peace process in cultural conflict: The role of the media. Conflict \& Communication Online, 2(1).

- Shinar, D. (2004). Media Peace Discourse: Constraints, Concepts and Building Blocks. Conflict \& Communication Online, 3(1/2).

- Tuchman, G. (1972). Objectivity as strategic ritual: an examination of newsmen's notions of objectivity. American Journal of Sociology, 77(4), 660-679.

- Ward, S. J. A. (2005). Journalism Ethics from the Public's Point of View. Journalism Studies, 6(3), 315-330.

- Ward, S. J. A. (2009). Journalism Ethics. In K. Wahl-Jorgensen \& T. Hanitzsch (Eds.), The Handbook of Journalism Studies (pp.295-308). New York: Taylor \& Francis.

- Wilkins, L., \& Brennen, B. (2004). Conflicted interests, contested terrain: journalism ethics codes then and now. Journalism Studies, 5(3), $297-309$.

- Wolfsfeld, G. (2001). The News Media and Peace Processes. The Middle East and Northern Ireland (United States Institute of Peace.). Washington.

- Wolfsfeld, G. (2004). Media and the Path to Peace. Cambridge University Press. 